\title{
MEDICINE
}

\section{УЛЬТРАСТУКТУРНА ОРГАНІЗАЦІЯ ГЕМОМІКРОЦИРКУЛЯТОРНОГО РУСЛА ШКІРИ БІЛОГО ЩУРА НА РАННІХ ЕТАПАХ ПЕРЕБІГУ ЕКСПЕРИМЕНТАЛЬНОГО СТРЕПТОЗОТОЦИН- ІНДУКОВАНОГО ЦУКРОВОГО ДІАБЕТУ}

\author{
Борис Р. Я., Блищак Н. Б., Михалевич М. М., Блищак Ю. З., Покотило П. Б. \\ Украӥна, Львів, Львівський національний медичний університет імені Данила Галицького
}

DOI: https://doi.org/10.31435/rsglobal_wos/30112019/6803

\section{ARTICLE INFO}

Received: 22 September 2019

Accepted: 08 November 2019

Published: 30 November 2019

\section{KEYWORDS}

angioarchitectonic,

skin,

diabetes

mellitus,

hemomicrocirculatory net, ultrastructure.

\section{ABSTRACT}

This article is presented information about electron microscopic characteristic the angioarchitectonics of hemomicrocirculatory white rat skin net in experimental streptozotocin-induced diabetes mellitus. Was used in the experiment 30 adult white male rats weighing 120-130 grams, which were maintained on a standard diet, had free access to food and water under normal conditions. The insulin-dependent form of type I diabetes mellitus was modeled by a single intraperitoneal injection of streptozotocin from Sigma at a rate of $7 \mathrm{mg}$ per $100 \mathrm{~g}$ of body weight of the animal (prepared on $0.1 \mathrm{M}$ citrate buffer, $\mathrm{pH}=4.5$ ). The development of experimental diabetes mellitus during 4 weeks was monitored by observing an increase in blood glucose, which was measured by the glucose oxidase method. Studies were performed on rats with glucose levels of $12.00 \mathrm{mmol} / \mathrm{l}$ and above. The experiment was carried out in accordance with the provisions of the European Convention for the Protection of Vertebrate Animals Used for Experimental and Other Scientific Purposes (Strasbourg, 1986), Council of Europe Directive 86/609 / EEC (1986). Rats were removed from the experiment by an overdose of intraperitoneal anesthesia using sodium thiopental (calculated at $25 \mathrm{mg} / \mathrm{kg}$ body weight of the animal). Applying the method of electron microscopy (the study and photographing of the material was carried out on an electron microscope EM-100 AK at an accelerating voltage of $75 \mathrm{kV}$ and magnification $6000-8000$ times). As a material for this examination, the skin intact from the internal surface of the thigh and the back of the white rats was used. The study showed that after 2 weeks of diabetes occure gradually and are progressing alterations of the skin's hemomicrocirculatory bed of white rats, which characterised mainly by small spasm of some vessels. The wall of the most vessels still had normal structure but revealed a narrowing of the capillaries due to the protrusion of the nuclear zone of the endothelial cells. After 4 weeks of the experimental streptozotocin-induced diabetes mellitus were already observed reconstruction practicaly all skin's microvessels of white rats. The lumen of the capillaries became irregular. The contours of the nuclei of endotheliocytes were elongated with an uniform homogen chromatyn, which is concentrated in lumps, thickened bazal membrane, observed proliferation of endothelial cells, which leads to narrowing of the lumen of blood vessels. At the end of the experiment, we observe the inclusion of compensatory properties of the organism the wall of blood vessels of the hemomicrocirculatory bed of the skin thickens, while the lumen of the microvessels become narrows. The results of investigation can be used in the practice medicine for diagnosis and treatment of skin's diseases in diabetes mellitus. 
Citation: Борис Р. Я., Блищак Н. Б., Михалевич М. М., Блищак Ю. З., Покотило П. Б. (2019) Ultrastructural Organization of Hemotomicrocirculatory net of White Rat Skin in the Early Stages of Experimental Streptozotocin-Induced Diabetes Mellitus. International Academy Journal Web of Scholar. 11(41), Vol.1. doi: 10.31435/rsglobal_wos/30112019/6803

Copyright: (C) 2019 Борис Р. Я., Блищак Н. Б., Михалевич М. М., Блищак Ю. З., Покотило П. Б. This is an open-access article distributed under the terms of the Creative Commons Attribution License (CC BY). The use, distribution or reproduction in other forums is permitted, provided the original author(s) or licensor are credited and that the original publication in this journal is cited, in accordance with accepted academic practice. No use, distribution or reproduction is permitted which does not comply with these terms.

Вступ. Цукровий діабет - одна з найважливіших соціально-економічних проблем клінічної ендокринології $[2,6,7]$. У 2000 році кількість хворих на цукровий діабет становила 175 млн., згідно 3 прогнозом міжнародного інституту діабету (Мельбурн) та інших дослідників на 2030 рік ця цифра складатиме 300 млн [3,9,11]. Відомо, що в осіб після 60 років захворюваність на діабет складає близько 10-15\%. Ця ендокринна патологія виявляє виражену тенденцію до зростання і складає на сьогодні близько $70 \%$ від усіх ендокринних захворювань $[1,10,23,24,25]$. Дослідження ультраструктурної організації гемомікроциркуляторного русла шкіри піддослідних тварин при цукровому діабеті є дуже важливим та актуальним питанням, оскільки пов'язане із масовим використанням білих щурів у постановці експериментальних патологічних процесів $[4,5,8,12,13]$. Проблема морфологічних змін у багатьох органах $[16,17,18,19,22]$, а особливо в шкірі при цукровому діабеті і до сьогодні залишається відкритою як для морфологів, так і для практикуючих лікарів. На даний час у літературі $є$ абсолютно недостатньо висвітлені питання щодо динаміки змін будови шкіри піддослідних тварин на різних термінах експериментального цукрового діабету 3 подальшим співставленням отриманих даних із клінічними [14,15,20,21].

Метою нашої роботи стало відтворення моделі стрептозотоцин-індукованого цукрового діабету на білих щурах та вивчення ультраструктури ангіоархітектоніки гемомікроциркуляторного русла шкіри тварин при даній патології.

Матеріали та методи. Експеримент проведений на 30-ти статевозрілих білих щурахсамцях масою тіла 120-130 грам, які утримувались на стандартній дієті, мали вільний доступ до їжі та води у нормальних умовах. Інсулінзалежну форму цукрового діабету I типу моделювали одноразовим внутрішньоочеревинним введенням стрептозотоцину фірми "Sigma" з розрахунку 7 мг на 100 г маси тіла тварини (приготованому на $0,1 \mathrm{M}$ цитратному буфері, $\mathrm{pH}=4,5$ ). Розвиток експериментального цукрового діабету протягом 4 тижнів контролювали, спостерігаючи за зростанням рівня глюкози в крові, яку вимірювали за допомогою глюкозооксидазного методу. Дослідження проводили на щурах з рівнем глюкози 12,00 ммоль/л і вище. Експеримент проведений у відповідності 3 положенням Свропейської конвенції щодо захисту хребетних тварин, яких використовують в експериментальних та інших наукових цілях (Страсбург, 1986), Директиви Ради Європи 86/609/EЕC (1986), Закону України №3447-IV “Про захист тварин від жорстокого поводження”. Щурів виводили 3 досліду шляхом передозування внутрішньо-очеревинного наркозу 3 використанням тіопенталу натрію (з розрахунку 25 мг/кг маси тіла тварини). Як матеріал для електронно-мікроскопічного дослідження використовували некроптати шкіри із присередньої поверхні стегна та спинки білих шурів. Лезом відрізали невелику частину шкіри із присередньої поверхні стегна і спинки тварини, помішали у велику краплю $2 \%$ розчину чотириокису осмію на 0,1M фосфатному буфері (pH 7,36) із сахарозою. Після цього знежиреним в ацетоні лезом вирізали смужки та швидко переносили їх в іншу краплю фіксуючого розчину такого ж складу, розмішеного на восковій пластинці (зуболікарський віск), яка знаходиться на льодяній плиті. Зі смужок вирізали шматочки, а саме тканинні блоки шкіри кубічної форми об'ємом 1мм3. Тканинні блоки фіксували у $2 \%$ розчині чотириокису осмію на $0,1 \mathrm{M}$ фосфатному буфері (pH 7,36) із доданням сахарози протягом 2 годин на льодяній бані. Після цього їх відмивали буферним розчином такого ж складу 4 свіжі порції по 15 хвилин у кожній. Для дегідратації і підготовки до просякнення водонерозчинними смолами відмиті від залишків фіксаторів тканинні блоки проводили через спирти висхідної концентрації та абсолютний ацетон. Після грубої заточки блоків під мікроскопом УМТП-2 виготовляли напівтонкі зрізи, що мали товщину 1 мкм, та забарвлювали їх 1\% розчином 
метиленового синього. Ультратонкі зрізи готували на ультрамікротомі УМТП-ЗМ із допомогою скляних ножів, виготовлених на приладі ССН-1. Вивчення та фотографування матеріалу проводилось на електронному мікроскопі ЕМ-100 АК при прискорюючій напрузі 75 кВ і збільшенні 4000-8000 разів.

Результати. Обговорення. При ультрамікроскопічному вивченні капілярів шкіри білих щурів експериментальної групи через 2 тижні перебігу стрептозотоцин-індукованого цукрового діабету нами було виявлено, що стінка переважної більшості судин ще зберігає нормальну будову. Проте, подекуди уже трапляються капіляри із звуженим просвітом як наслідок випинання ядровмісної зони ендотеліоцитів.

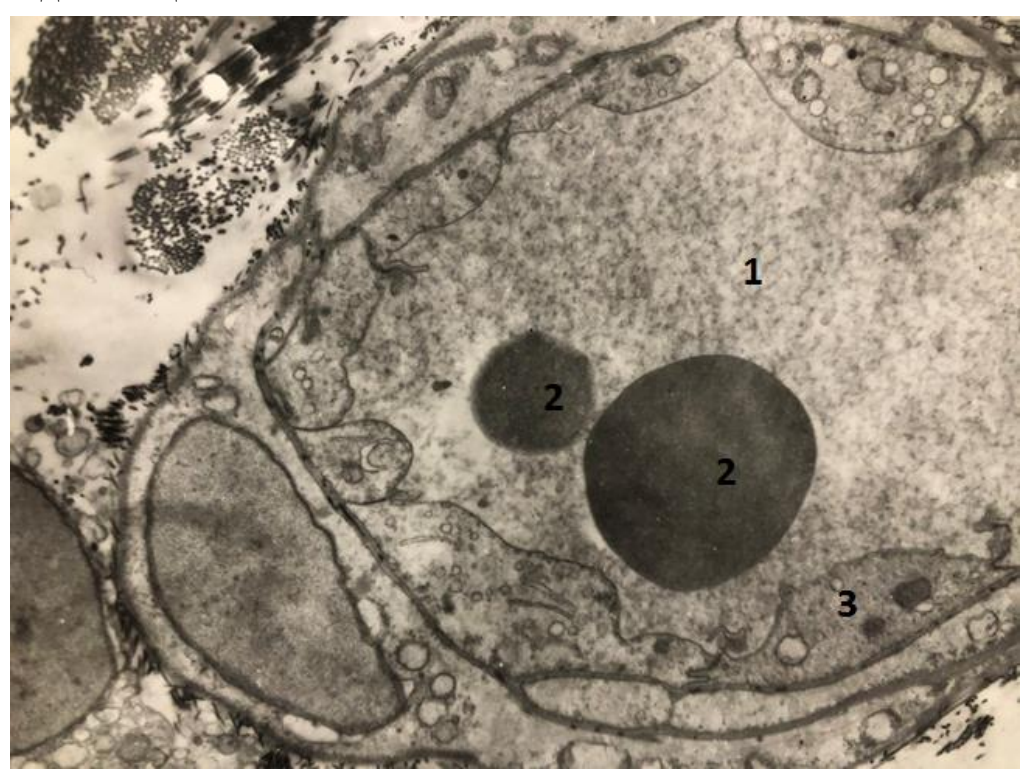

Рис. 1. Капіляр сосочкового шару шкіри присередньої поверхні лапки білого щура через 2 тижні перебігу експериментального иукрового діабету. Електронна мікрофотографія. X4000.

1 - звуження просвіту мікросудини; 2 - еритроцити у просвіті; 3 - випинання ядровмісної зони ендотеліоцита.

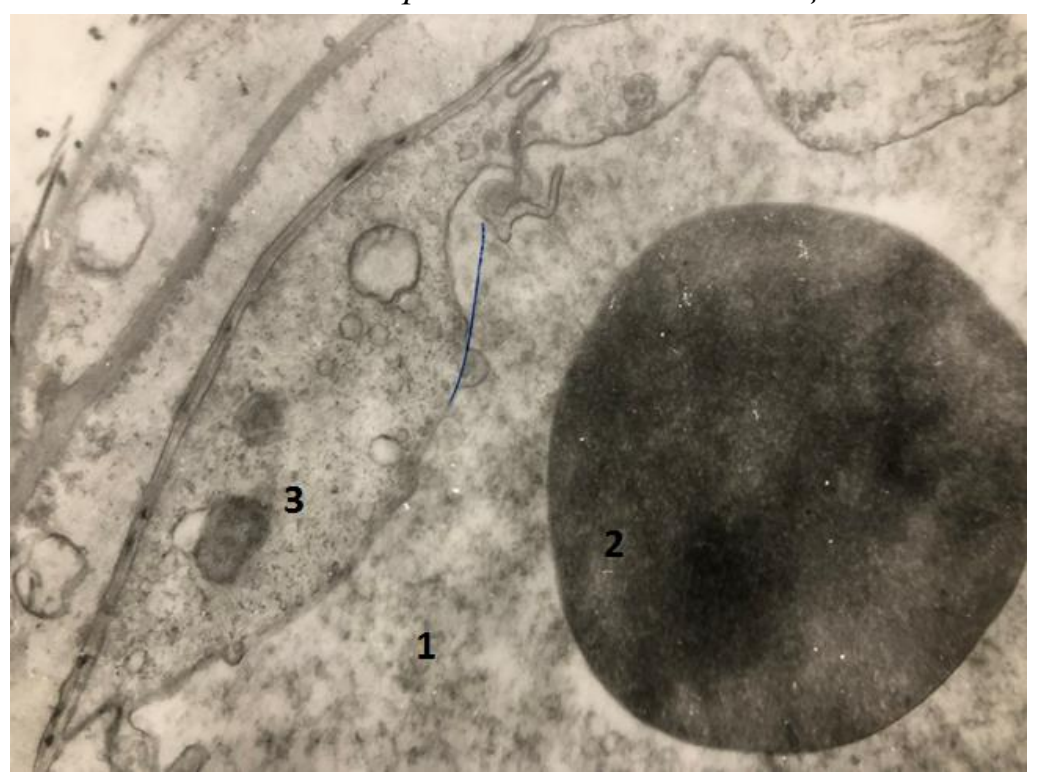

Рис. 2. Капіляр сосочкового шару шкіри спинки білого шура через 2 тижні перебігу експериментального иукрового діабету. Електронна мікрофотографія. Х4000. 1 - звуження просвіту; 2 - еритроцити у просвіті мікросудини; 3 - випинання ядра ендотеліоцита.

Ядра 3 глибокими інвагінаціями каріолеми мають неправильну форму, а по їх периферії спостерігаються численні ядерні пори. Цитоплазма одних ендотеліоцитів розширена, інших ущільнена та має вигляд смужки i представлена великою кількістю полісом, рибосом та мікропіноцитозних пухирців. Електроннооптична щільність цитоплазми є завищеною у порівнянні 
3 контролем, кількість органел зменшується. Базальна мембрана звивиста, подекуди іще зберігає свою суцільність, але в деяких ділянках уже потовщена без чіткого зовнішнього контуру. Гранулярна ендоплазматична сітка представлена розширеними трубочками, які містять поодинокі рибосоми, комплекс Гольджі - цистернами та великою кількістю світловмісних пухирців.

Через 4 тижні експериментального стрептозотоцин-індукованого цукрового діабету в капілярах вже відзначаємо значні зміни - стінка мікросудин потовщується, натомість просвіт звужується. Ендотеліоцити набряклі, у їхній цитоплазмі спостерігаються численні мітохондрії та вільні рибосоми. Ядерна частина цитоплазми випинається у просвіт гемокапіляра, як і апікальна плазмолема, що у деяких місцях випинання у просвіт судини утворює мікроворсинки.

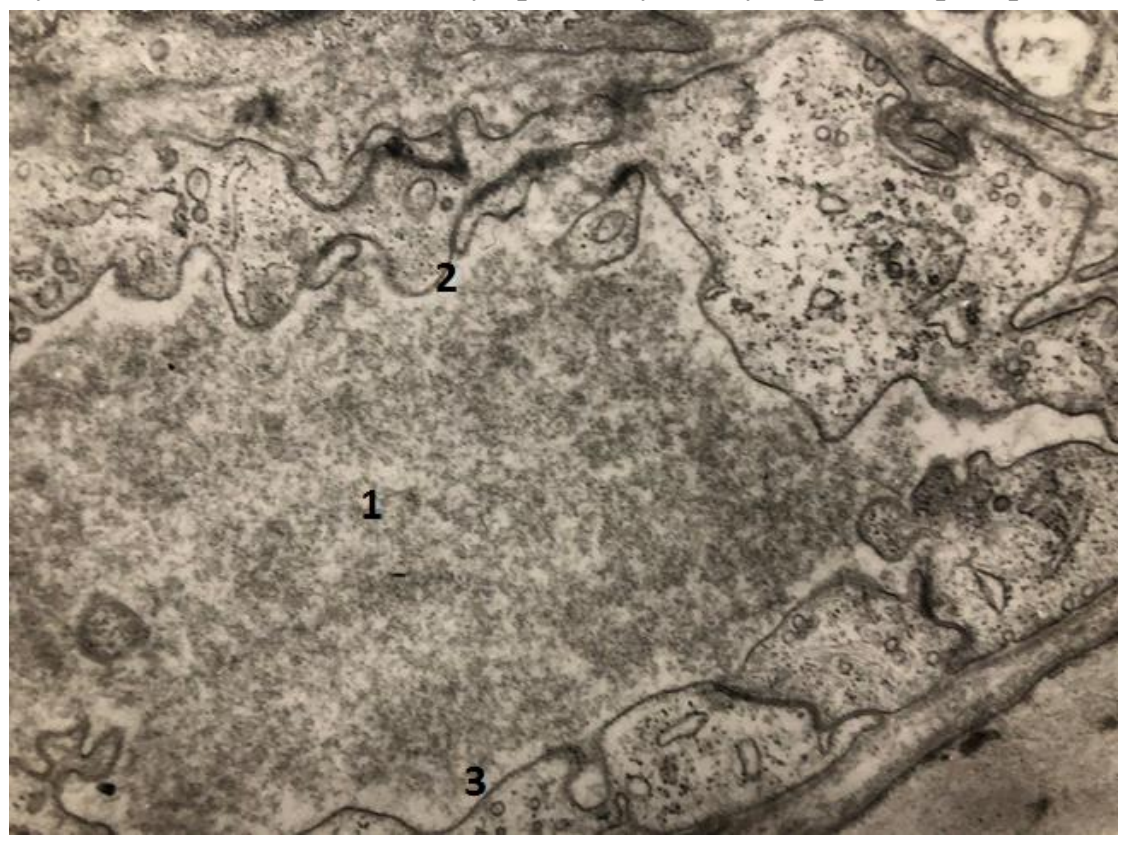

Рис. 3. Капіляр сосочкового шару шкіри спинки білого щура через 4 тижні перебігу експериментального иукрового діабету. Електронна мікрофотографія. Х8000. 1 - набряклий ендотеліоцит; 2 - иитолема ендотеліоцита; 3 - базальна мембрана.

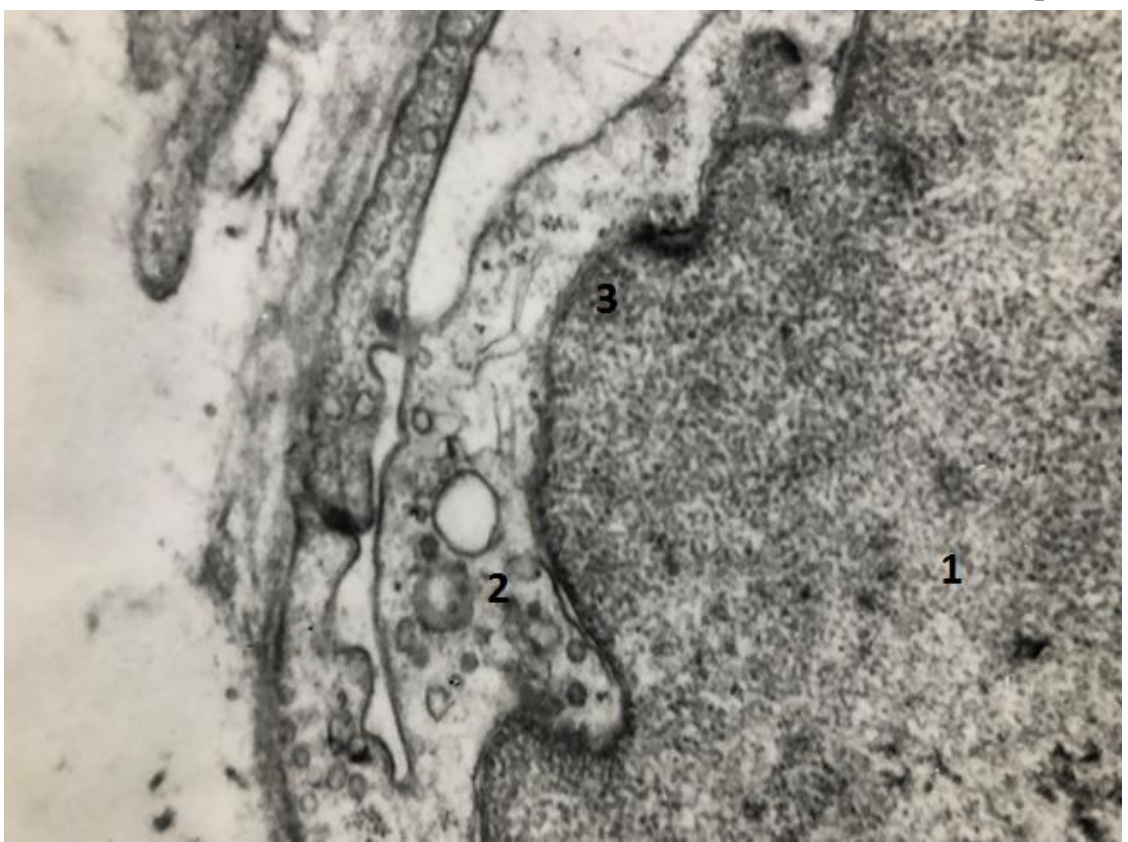

Рис. 4. Капіляр сосочкового шару шкіри присередньої поверхні лапки білого щура через 4 тижні перебігу експериментального иукрового діабету. Електронна мікрофотографія. Х8000. 1 ендотеліочит, що набрякає; 2 - цичтолема ендотеліочита; 3 - базальна мембрана. 
Ендоплазматична гранулярна сітка представлена вакуолями у вигляді поодиноких трубочок із "мутним" вмістом. Комплекс Гольджі містить досить розширені пухирці. У мітохондрій визначається чітка зовнішня мембрана та розріджений матрикс із поодинокими кристами. Набряклі відростки перицитів щільно охоплюють капіляри. 3 боку самої апікальної поверхні в цитоплазмі ендотеліоцитів чітко візуалізуються заокруглені електроннооптичнощільні тільця. Відмічається зменшення трансендотеліального транспорту та проникності стінки капілярів внаслідок відсутності мікропіноцитозних пухирців.

\section{Висновки та перспективи подальших розробок.}

1. Через 2 тижні перебігу стрептозотоцин-індукованого цукрового діабету виникають та поступово прогресують зміни ланок гемомікроциркуляторного русла шкіри білих щурів, що проявляються незначним спазмом окремих судин. Стінка більшості судин має нормальну будову, та вже подекуди трапляються капіляри із звуженим просвітом внаслідок випинання ядровмісної зони ендотеліоцитів.

2. Через 4 тижні експерименту спостерігається перебудова практично усіх мікросудин гемомікроциркуляторного русла шкіри білих щурів. Просвіт капілярів набуває неправильної форми. Контури ядер ендотеліоцитів втрачають свою чіткість, стають видовженої відросчатої форми 3 однорідним хроматином, який починає концентруватися в грудочки, базальна мембрана потовщується, відмічаємо ознаки проліферації ендотеліоцитів, які призводять до значного звуження просвіту судин.

3. Під кінець експерименту спостерігаємо включення компенсаторних властивостей організму - стінка судин гемомікроциркуляторного русла шкіри потовщується, натомість просвіт мікросудин звужується.

4. Дані проведеного дослідження ангіоархітектоніки шкіри можуть бути використані у подальшому в практичній медицині для поглиблення вивчення та лікування іï патології при цукровому діабеті.

\section{ЛIТЕРАТУРА}

1. Товажнянская ЕЛ, Безуглова ИО, Дубинская ОИ, Каук ОИ, Резниченко ЕК, Коряк ВВ. Эндотелиальная дисфункция и цереброваскулярная патология у больных сахарным диабетом. Міжнародний медичний журнал. 2014;13:26-30.

2. Босевски М. Диабетическая ангиопатия. Ангиология и сосудистая хірургія. 2011;17.4. С.14-23.

3. Rozario T, DeSimone DW. The extracellular matrix in development and morphogenesis: a dynamic view. Dev Biol. 2010 May 1;341(1):126-140.

4. Комнацький БЮ, Кулигіна ВМ. Динаміка гематологічних та біохімічних показників периферичної крові щурів за умов експериментального цукрового діабету з модульованим імобілізаційним стресом при введенні анестезуючих засобів. Вісник стоматології. 2013;1:10-17.

5. Красний МР. Вплив вітаміну С та Е на ультраструктурні зміни гемокапілярів нирок у білих щурів зі стрептозотоциновим діабетом. Клінічна та експериментальна патологія. 2011;10.2(2):56-58.

6. Лисенко ТП. Судинні ускладнення цукрового діабету: сучасні методи інструментальної діагностики. Медицина сьогодні і завтра. 2014;1:73-77.

7. Онисько РМ, Пальтов СВ, Фік ВБ. Морфогенетичні та морфологічні аспекти судинних ускладнень цукрового діабету. Практична медицина. 2012;18(5):98-108.

8. Гнатів ВВ, Демчак ХС, Бабуленко ОМ. Активні форми кисню в патогенезі ангіопатій при цукровому діабеті 2-го типу. Медична та клінічна хімія. 2013;15(1):145-149.

9. Тюренков ИН, Воронков АВ, Слиецанс АА. Роль эндотелиальной дисфункции в развитии сосудистых осложнений сахарного диабета. Пат. физиология и эксперим. терапия. 2013;2:80-84.

10. Товажнянская ЕЛ. Эндотелиальная дисфункция. Клинические аспекты проблемы и пути ее решения. Журнал неврології ім. Б. М. Маньковського. 2016;3:17-21.

11. Нечитайло ОЮ, Коновчук ВМ, Юхимець ІО. Особливості мікроциркуляції у пацієнтів із ускладненим цукровим діабетом. Буковинський медичний вісник. 2015;19(2):141-144.

12. Ступина АC, Квитницкая-Рыжова ТЮ. Возрастные особенномти ультраструктурних изменений стенки аорты при моделировании сахарного диабета. Український морфологічний альманах. 2008;6(1):218-219.

13. Кривко ЮЯ, Матешук-Вацеба ЛР, Масна 33, Пальтов ЄВ, Кирик ХА. Ультраструктура ланок гемомікроциркуляторного русла в нормі та за умов експериментального цукрового діабету. Вісник морфології. 2010;16(2):397-400.

14. Покотило ПБ, Логаш МВ, Покотило ВЮ. Гістологічне дослідження нирки щура на ранніх термінах перебігу експериментального цукрового діабету. Судово-медична експертиза. 2014;1:23-25 
15. Adeghate E, Singh J. Structural changes in the myocardium during diabetes-induced cardiomyopathy. Heart Fail. Rev. 2014;19(1):15-23.

16. Amann K, Benz K. Structural renal changes in obesity and diabetes. Semin. Nephrol. 2013;33(1):23-33.

17. Wang C, Fu K, Liu H, Xing F, Zhang S. Brain structural changes and their correlation with vascular disease in type 2diabetes mellitus patients: a voxel-based morphometric study. Neural. Regen. Res. 2014;9(16):1548-1556.

18. Keymel S, Heinen Y, Balzer J, Rassaf T, Kelm M, Lauer T, et al.]. Characterization of macro- and microvascular function and structure in patients with type 2 diabetes mellitus. Am. J. Cardiovasc. Dis. 2011;1(1):68-75.

19. Pacifici F, Arriga R, Sorice GP, Capuani B, Scioli MG, Pastore D, et al. Peroxiredoxin 6, a novel player in the pathogenesis of diabetes. Diabetes. 2014;63(10):3210-3220.

20. Van Geest RJ, Leeuwis JW, Dendooven A, Pfister F, Bosch K, Hoeben KA, et al.]. Connective tissue growth factor is involved in structural retinal vascular changesin long-term experimental diabetes. J. Histochem. Cytochem. 2014;62(2):109-118.

21. To M, Goz A, Camenzind L, Oertle P, Candiello J, Sullivan M, et al.]. Diabetes-induced morphological, biomechanical, and compositional changes in ocular basement membranes. Exp. Eye. Res. 2013;116:298-307.

22. Davies-Tuck ML, Wang Y, Wluka AE, Berry PA, Giles GG, English DR, et al. Increased fasting serum glucose concentration is associated with adverse knee structural changes in adults with no knee symptoms and diabetes. Maturitas. 2012;72(4):373-378.

23. Eltayeb AA, Ahmad FA, Sayed DM, Osama AM. Subclinical vascular endothelial dysfunctions and myocardial changes with type 1diabetes mellitus in children and adolescents. Pediatr. Cardiol. 2014;35(6):965-974.

24. Lockhart CJ, McCann AJ, Pinnock RA, Hamilton PK, Harbinson MT, McVeigh GE. Multimodal functional and anatomic imaging identifies preclinical microvascular abnormalities in type 1 diabetes mellitus. Am. J. Physiol. Heart Circ. Physiol. 2014;307(12):1729-1736.

25. Gkogkolou P, Böhm M. Skin disorders in diabetes mellitus. J. Dtsch. Dermatol. Ges. 2014;12(10):847-863. 